\title{
Synthesis of chiral pyridino-15-crown-5 type ligands containing $\alpha$-D-hexapyranoside unit and their application in asymmetric synthesis
}

\author{
Attila Makó, ${ }^{a}$ Péter Bakó, ${ }^{a} *$ Áron Szöllősy, ${ }^{b}$ Tibor Bakó, ${ }^{c}$ Csaba Peltz, \\ and Péter Keglevich ${ }^{\mathrm{a}}$ \\ ${ }^{a}$ Department of Organic Chemistry and Technology, Budapest University of Technology and \\ Economics, 1521 Budapest, P.O. Box 91, Hungary \\ ${ }^{b}$ Department of General and Analytical Chemistry, 1525 Budapest, P.O. Box 17,Hungary \\ ${ }^{c}$ Spectroscopic Department, EGIS Pharmaceuticals PLC, 1106 Budapest, Keresztúri út 30-38. \\ 1475 Budapest, 10. P.O.Box 100, Hungary \\ E-mail:pbako@mail.bme.hu
}

\begin{abstract}
The synthesis of novel chiral monoaza-15-crown-5 compounds (1-4) with pyridine-ring starting from methyl-4,6- $O$-benzylidene- $\alpha-D$-glucopyranoside and methyl-4,6- $O$-benzylidene- $\alpha-D$ mannopyranoside by different methods are reported. These crown ethers showed significant asymmetric induction in a Michael addition (up to $80 \%$ ee).
\end{abstract}

Keywords: Asymmetric catalysis, crown compounds, ring closure, phase-transfer catalysis, Michael addition

\section{Introduction}

The application of chiral crown ethers find increasing interest in asymmetric organic synthesis. ${ }^{1}$ Crown ethers with carbohydrate moieties form a special group of optically active crown ethers. The inexpensive, natural, non toxic sugars are attractive starting materials for the synthesis of chiral macrocycles. Therefore, these compounds should serv as useful tools for the separation of enantiomers, chiral recognition in enzymatic reactions and for the control of asymmetric reactions. ${ }^{2}$ Stoddart et al. were the first group that published the enantiomeric discriminating ability of certain sugar-based crown compounds towards the antipodes of chiral ammonium salts. ${ }^{3}$ Although many optically active macrocycles incorporating one or more monosaccharide units have been synthesized, only a few have been successfully applied as catalysts in asymmetric reactions. ${ }^{4}$ The nature of the crown ether, especially with reference to its chirality, its 
rigidity and the micro-environment of its cavity, can all be expected to play a significant role in its functions as a catalyst.

We have previously reported the synthesis of new hexapyranoside-based monoaza 15crown-5 type lariat ethers with different side-arms containing a heteroatom at the end. ${ }^{5}$ These chiral macrocycles proved to be effective asymmetric catalysts in some asymmetric Michael additions, ${ }^{6}$ Darzens condensations ${ }^{6}$ and epoxidations of double-bond. ${ }^{7}$ We focused on the synthesis of the analogue hexapyranoside-based crown ethers incorporating a pyridine unit that were expected to exhibit a more rigid structure. It is known that a more rigid structure is always better from the point of view of enantiomeric discrimination. Mention that it is the Lewis basicity of the pyridine moiety that allows for this discrimination. Besides some of these crown ethers were utilized in the resolution of racemates. ${ }^{8}$ We report herein a convenient synthesis of optically active crown ethers $\mathbf{1}-\mathbf{4}$ containing two different monosaccharide-units. Changing the substituents on the pyridine ring of the macrocycle 1 can make them suitable for various purposes. For example a methoxy group (2) changes the liphophylity of the molecule (that can be phase transfer catalyst) while an allyloxy group (3) makes possible the attachment of the ligand to silica gel ${ }^{9}$ (Figure 1.).

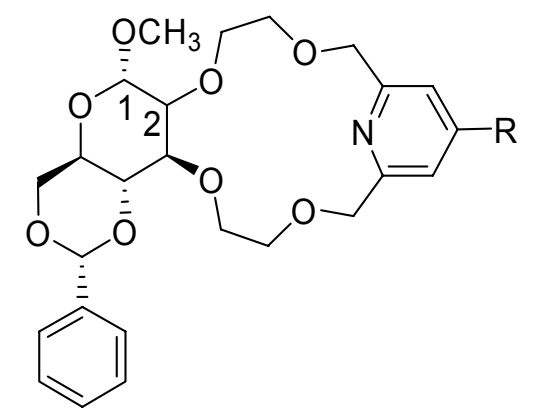

$\alpha-D$-Glucopyranoside unit 2C $\ldots \cdots ! \cdot$ O

$1 \mathrm{R}=\mathrm{H}(40 \%)$

$2 \mathrm{R}=\mathrm{OCH}_{3}(29 \%)$

$3 \mathrm{R}=\mathrm{OCH}_{2} \mathrm{CH}=\mathrm{CH}_{2}(33 \%)$

$\alpha$-D-Mannopyranoside unit $2 \mathrm{C}-\mathrm{O}$

$4 \mathrm{R}=\mathrm{H}(21 \%)$

\section{Figure 1}




\section{Results and Discussion}

Methods were elaborated in order to synthesize novel chiral monoaza-15-crown-5 compounds (1-4) that incorporate pyridine moieties starting from methyl-4,6- $O$-benzylidene- $\alpha-D$ glucopyranoside and methyl-4,6- $O$-benzylidene- $\alpha-D$-mannopyranoside. The key compounds of the syntheses are the 2,6-pyridinedimethyl ditosylates $(\mathbf{6 , 9}, \mathbf{1 4}, \mathbf{1 6}) .^{10}$

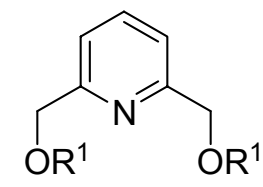

$5 \quad \mathrm{R}^{1}=\mathrm{H}(74 \%)$

$6 \mathrm{R}^{1}=\mathrm{Ts}(87 \%)$

$7 \mathrm{R}^{1}=\mathrm{CH}_{2} \mathrm{COOCH}_{3}(72 \%)$

$8 \mathrm{R}^{1}=\mathrm{CH}_{2} \mathrm{CH}_{2} \mathrm{OH}(83 \%)$

$9 \mathrm{R}^{1}=\mathrm{CH}_{2} \mathrm{CH}_{2} \mathrm{OTs}(80 \%)$

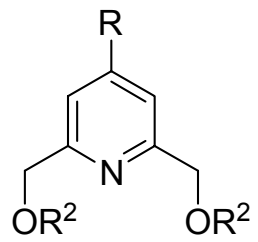

$13 \mathrm{R}=\mathrm{OMe}, \mathrm{R}^{2}=\mathrm{H}(67 \%)$

$14 \mathrm{R}=\mathrm{OMe}, \mathrm{R}^{2}=\mathrm{Ts}(68 \%)$

$15 \mathrm{R}=\mathrm{OCH}_{2} \mathrm{CH}=\mathrm{CH}_{2}, \mathrm{R}^{2}=\mathrm{H}(62.5 \%)$

$16 \mathrm{R}=\mathrm{OCH}_{2} \mathrm{CH}=\mathrm{CH}_{2}, \mathrm{R}^{2}=\mathrm{Ts}(79 \%)$

\section{Figure 2}

Several possible ways were described for the preparation of 2,6-pyridinedimethyl bistosylate 6. ${ }^{11}$ In our case 2,6-bis(hydroxymethyl)pyridine $\mathbf{5}^{12}$ was treated with p-toluenesulfonyl chloride in a mixture of THF and $40 \%$ aqueous $\mathrm{NaOH}$ at low temperature ${ }^{13}$ to give bistosylate $6(87 \%$ yield). The synthesis of the "half-crown" diol containing a pyridyl unit $\mathbf{8}$ was accomplished by the reaction of diol 5 with methyl bromoacetate in the presence of sodium hydride in THF under reflux to afford diester 7 ( $72 \%$ yield), which was converted to diol 8 by reduction with $\mathrm{NaBH}_{4}$ in ethanol at ambient temperature $(83 \%) .{ }^{14}$ The ditosylate derivative 9 was obtained by the treatment of diol $\mathbf{8}$ with two equivalents of p-toluenesulfonic chloride in the presence of finely pulverized $\mathrm{KOH}$ at low temperature in THF (product 9 was obtained in a $80 \%$ yield). ${ }^{15}$ Compound 9 was observed to be somewhat unstable (Figure 2).

The dimethyl chelidamate $\mathbf{1 0}$ was synthesized by a method described in the literature. ${ }^{11}$ Diester 10 was treated with dimethyl sulfate or allyl bromide in DMF, in the presence of $\mathrm{K}_{2} \mathrm{CO}_{3}$, to obtain 4-substituted dimethyl 2,6-pyridinedicarboxylates $\mathbf{1 1}$ and 12, respectively (see Scheme 1). Diesters 11 and 12 were reduced with $\mathrm{NaBH}_{4}$ in ethanol and the crude ethanol free 2,6pyridinedimethanol derivatives 13 and 15 so obtained were treated with p-toluenesulfonyl chloride in a mixture of THF and aqueous $\mathrm{NaOH}$ at low temperature to give bistosylate $\mathbf{1 4}$ and 16, respectively (Scheme 1). ${ }^{11}$ 


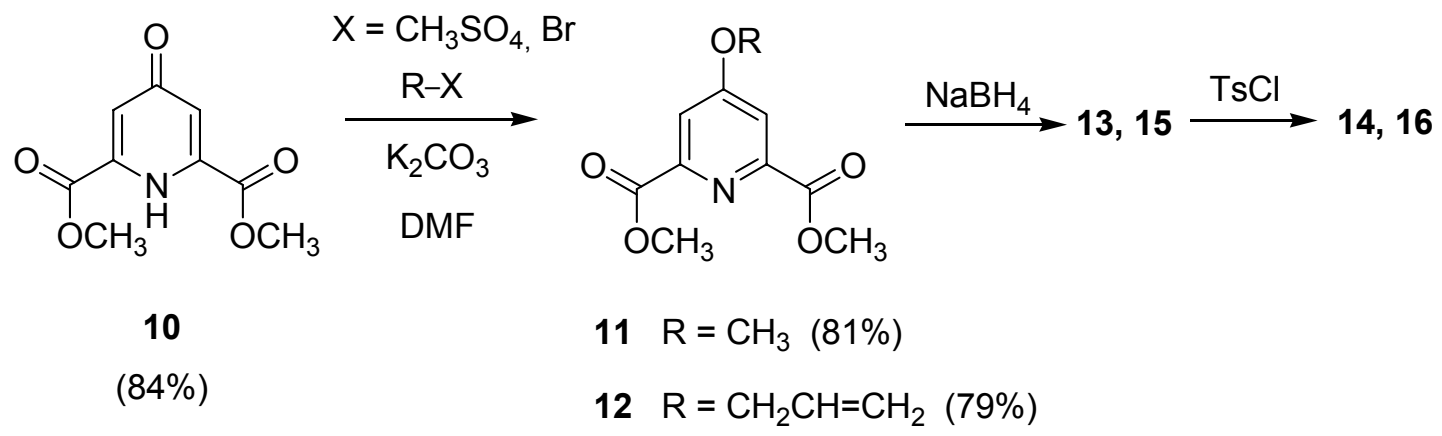

Scheme 1. Synthesis of 4-methoxy- and 4-allyloxy-2,6-pyridinedimethyl ditosylate $(\mathbf{1 4 , 1 6 )}$ respectively, $\mathrm{R}-\mathrm{X}$ means $\left(\mathrm{CH}_{3}\right)_{2} \mathrm{SO}_{4}$ and $\mathrm{CH}_{2}=\mathrm{CH}-\mathrm{CH}_{2} \mathrm{Br}$.<smiles>CO[C@H]1O[C@@H]2CO[C@@H](c3ccccc3)O[C@H]2[C@H](O)[C@H]1O</smiles>

\begin{tabular}{|c|c|c|}
\hline & $\begin{array}{c}\alpha-D-G l u c o p y r a n o s i d e \\
2 \mathrm{C}\end{array}$ & $\begin{array}{c}\alpha-\mathrm{D}-\text { Mannopyranoside } \\
2 \mathrm{C} \longrightarrow \mathrm{OY}\end{array}$ \\
\hline$Y=H$ & 17 & 21 \\
\hline $\mathrm{Y}=\mathrm{CH}_{2} \mathrm{COOH}$ & $18(78 \%)$ & $22(76 \%)$ \\
\hline $\mathrm{Y}=\mathrm{CH}_{2} \mathrm{CH}_{2} \mathrm{OH}$ & $19(80 \%)$ & $23(68 \%)$ \\
\hline $\mathrm{Y}=\mathrm{CH}_{2} \mathrm{CH}_{2} \mathrm{OTs}$ & $20(67 \%)$ & \\
\hline
\end{tabular}

Figure 3

Our chiral compounds were the "half-crown" diol 19 containing a glucopyranoside-unit and its bistosylate derivative 20, as well as the diol $\mathbf{2 3}$ containing a mannopyranoside moiety (Figure 3). The methyl-4,6-O-benzylidene- $\alpha$-D-glucopyranoside 17 was treated with sodium chloroacetate in DMF in the presence of sodium hydride to give chiral dicarboxylic 18 (78\%), which was reduced with a mixture of $\mathrm{NaBH}_{4}$ and $\mathrm{I}_{2}$ in THF to result in the sugar-based diol 19 in a $80 \%$ yield after chromatography. Compound 19 was synthesized earlier in four steps including ozonolysis as described by Stoddart et al. (in 51\% yield from methyl-4,6- $O$-benzylidene- $\alpha-D$ glucopyranoside). ${ }^{16}$ The reaction of diol 19 with p-toluenesulfonyl chloride in THF/aqueous $\mathrm{NaOH}$ furnished bistosylate $\mathbf{2 0}$ in a yield of $67 \%$ after column chromatography. The dicarboxylic with a mannopyranoside-unit $\mathbf{2 2}$ and the corresponding diol $\mathbf{2 3}$ were obtained from the methyl4,6-O-benzylidene- $\alpha$-D-mannopyranoside 21 in a similar way. Compound $\mathbf{2 3}$ was prepared earlier from the 2,3-di-O-tert-butylester derivative by reduction with $\mathrm{LiAlH}_{4}(81 \%$ yield for the two steps). ${ }^{17}$ As far as we experienced, this method gave 23 in a low yield (50\%). The reducing agent $\mathrm{NaBH}_{4}+\mathrm{I}_{2}$ described by Periasamy ${ }^{18}$ gave, however, the sugar-based diols $\mathbf{1 9}$ and 23 in good yields after column chromatography. Our method possesses some advantages since it avoids the ozonolysis ${ }^{16}$ of the diallylderivatives of $\mathbf{1 7}$ and reduction ${ }^{17}$ with $\mathrm{LiAlH}_{4}$ respectively. 


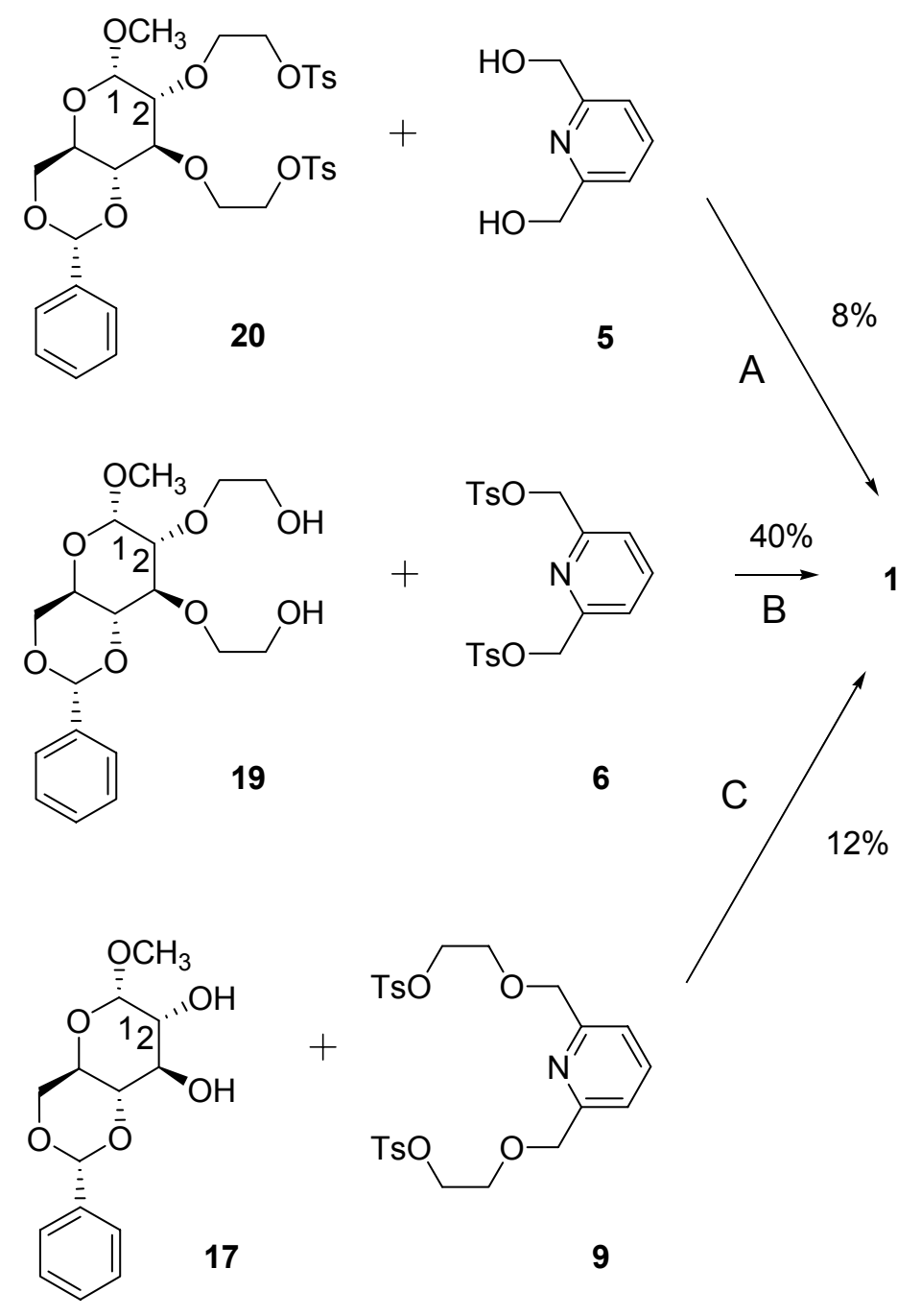

Scheme 2. Preparation of chiral pyridino-crown ether 1 by different methods (reaction conditions: $\mathrm{NaH}, \mathrm{DMF}, 60^{\circ} \mathrm{C}, 40 \mathrm{~h}$ ).

The synthesis of crown ether 1 was attempted using three different ring closure reactions by varying the coupling partners as shown in Scheme 2. (Methods A, B and C, in DMF in the presence of $\mathrm{NaH}$ ). The reaction of 2,6-bis(hydroxymethyl)pyridine 5 with glucopyranosidebased diol-ditosylate $\mathbf{2 0}$ (Method A) provided macrocycle $\mathbf{1}$ in only $8 \%$ yield. In another version, the reaction of 2,6-pyridinedimethyl ditosylate 6 with 19 glucopyranoside-based diol (Method B) afforded crown ether $\mathbf{1}$ in $40 \%$ yield. The ring forming reaction of ditosylate derivative $\mathbf{9}$ and sugar derivative 17 (Method $\mathrm{C}$ ) was not really efficient, as the yield of 1 was only 12\%. The yield difference of methods A, B and C may be the consequence of the success of the template effect within both reagents in the intramolecular ring closure reaction. The template effect can be characterized by the complexing abilty of the reagents towards $\mathrm{Na}^{+}$cation. The binding power of the reagents was measured in solution (NBA) in the presence of sodium picrate salt by FAB$\mathrm{MS}^{19-21}$ to achieve a fast and qualitative screening of the complexation ability of compounds $\mathbf{5}$, 
6, 9, 19 and 20. Table 1 summarizes the relative peak intensities (PI) of [ligand $+\mathrm{Na}]^{+}$as compared to uncomplexated [ligand +1$]^{+}$that was regarded to be $100 \%$.

Table 1. Sodium binding ability of compounds 5, 6, 9, 19, 20 on the basis of FAB-MS measurements ${ }^{\text {a }}$

\begin{tabular}{cccccc}
\hline & \multicolumn{6}{c}{ Reagents of ring closure reactions } \\
\hline Compounds & $\mathbf{5}$ & $\mathbf{6}$ & $\mathbf{9}$ & $\mathbf{1 9}$ & $\mathbf{2 0}$ \\
$P I=[\mathrm{M}+23]^{+} /[\mathrm{M}+\mathrm{H}]^{+}$ & 2.8 & 44 & 1450 & 410 & 900 \\
\hline
\end{tabular}

${ }^{\mathrm{a}}$ On the basis of relative peak intensities in the presence of sodium picrate salt in NBA matrix, assuming that all ligands form similar 1:1 complex.

As indicated in Table 1 the strong complexing ability of 20 ( $P I=900)$ and the weak complexing ability of $\mathbf{5}(P I=2.8)$ result in only a low yield in the ring closure reaction. In contrary, the complexing ability of ditosylate 6 is increased $(P I=44)$ and the half-crown diol 19 even owes a bigger value $(P I=410)$. This is in accordance with the relatively good yield of $40 \%$ obtained by Method B. Regarding Method C, the excellent complex forming ability of compound $9(P I=1450)$ is not enough as the hydroxy groups of sugar derivative $\mathbf{1 7}$ are of low reactivity. This situation results in the low yield of $12 \%$. One of our interesting observations is that the incorporation of the tosyl groups results in better coordinating ability for the diols (template effect). For example for 20 created from 19, the $P I$ value is almost doubled $\left(P I_{19}=\right.$ $\left.410 \rightarrow P I_{20}=900\right)$. This effect has a special importance in the case of compound 5 that has only a week coordinating ability $\left(P I_{5}=2.8\right)$. Tosylation of 5 results in a 15 -fold increase of value $P I$ $\left(P I_{6}=44\right)$. This effect has already been observed earlier in respect to crown ethers. ${ }^{22}$ It is worth mentioning that beside of the template effect, other circumstance may also play a role in the yield of the ring closure reaction. We have not studied the ability to elimination of tosylates. It is assumed that method B is favored also because compound $\mathbf{6}$ can undergo only substitution, in contrast to the case of $\mathbf{2 0}$ and $\mathbf{9 .}$

The methoxy- and allyloxy-macrocycles with pyridine ring ( $\mathbf{2}$ and $\mathbf{3}$, respectively) were prepared by Method B. The crown ether 2 was prepared by the reaction of pyridine derivative 14 and sugar-based diol component 19 in 29\% yield. Similarly, the reaction of 16 and 19 afforded macrocycle 3 in 33\% yield. The $\alpha-D$-mannopyranoside-based macrocycle 4 was prepared in an analogue way. The reaction of methyl-4,6-O- $\alpha-D$-mannopyranoside (21) with sodium chloroacetate gave bisacid derivative $\mathbf{2 2}$, the reduction of which led to $\mathbf{2 3}$ bis-glycol. The reaction of "half crown-diol" $\mathbf{2 3}$ and ditosyl derivative $\mathbf{6}$ resulted in the formation of mannopyranoside-based macrocycle 4 in a yield of $21 \%$. It is noted that compound 4 differs only from 1 in the configuration of its $\mathrm{C}(2)$ atom in the sugar moiety. In the glucopyranoside-based 1 the position of the $\mathrm{C}(2)-\mathrm{O}$ and $\mathrm{C}(3)-\mathrm{O}$ groups is trans, while that is cis in 4 . It was observed from the FAB-MS spectroscopy of the crude products that the glucopyranoside-based crown ethers were mainly formed as sodium complexes, while the mannopyranoside-based macrocycle 
was present in the crude products in an uncomplexed form. On purification by chromatography on alumina, the complexes were decomposed.

Chiral crown ethers 1-4 were tested in the Michael addition of 2-nitropropane to chalcone (Scheme 3). The solid-liquid phase transfer catalytic reaction was carried out at room temperature in dry toluene, in the presence of solid sodium tert-butoxide $(35 \mathrm{~mol} \%)$ and one of the chiral catalysts $\mathbf{1 - 4}$ prepared $(7 \mathrm{~mol} \%)^{6}$
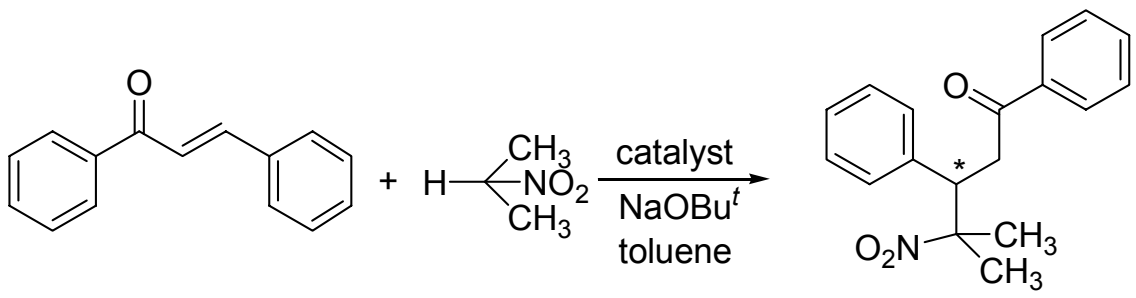

24

Scheme 3. Asymmetric addition of 2-nitropropane to chalcone.

Table 2. The effect of the crown ether catalysts 1-4 on the enantioselectivity in the addition of 2nitropropane to chalcone at room temperature

\begin{tabular}{cccccc}
\hline Entry & Catalyst & Time $(\mathrm{h})$ & ${\text { Yield of } \mathbf{2 4}(\%)^{\mathrm{a}}}^{\mathrm{a}}$ & {$[\alpha]_{\mathrm{D}}^{\mathrm{b}}$} & $\mathrm{ee}^{\mathrm{c}}(\%)$ \\
\hline 1 & $\mathbf{1}$ & 24 & 48 & -58.2 & $72(S)$ \\
2 & $\mathbf{2}$ & 30 & 47 & -61.4 & $76(S)$ \\
3 & $\mathbf{3}$ & 30 & 51 & -54.1 & $67(S)$ \\
4 & $\mathbf{4}$ & 25 & 50 & +64.6 & $80(R)$ \\
\hline
\end{tabular}

${ }^{\mathrm{a}}$ Based on isolation by preparative TLC. ${ }^{\mathrm{b}} \mathrm{In} \mathrm{CH}_{2} \mathrm{Cl}_{2}$ at $20{ }^{\circ} \mathrm{C}$. ${ }^{\mathrm{c}}$ Determined by ${ }^{1} \mathrm{H} \mathrm{NMR}$ spectroscopy in the presence of $\mathrm{Eu}(\mathrm{hfc})_{3}$ as chiral shift reagent. Absolute configuration were assigned by comparison of specific rotation with literature value. ${ }^{6 a}$

In all cases, the products were isolated by preparative TLC after the usual work-up procedure. The enantiomeric excess (ee) was determined by ${ }^{1} \mathrm{H}$ NMR spectroscopy using $(+)$ $\mathrm{Eu}(\mathrm{hfc})_{3}$ as a chiral shift reagent. The experimental data are shown in Table 2. It can be seen that glucopyranoside-based macrocycle 1 gave the product $\mathbf{2 4}$ in $48 \%$ yield and in $72 \%$ ee in favour of the $S$ enantiomer. ${ }^{6 c}$ It is also seen that the substituents in the pyridine ring influence the enantioselectivity to only a small extent; in the presence of catalyst $2\left(\mathrm{R}=\mathrm{OCH}_{3}\right)$ and $\mathbf{3}$ $\left(\mathrm{R}=\mathrm{OCH}_{2} \mathrm{CH}=\mathrm{CH}_{2}\right)$ the ee was 76 and $67 \%$, respectively. It is interesting, that while the glucopyranoside-based crown ethers (1-3) induce the formation of the (-)-(S)-enantiomer of the Michael adduct, the mannopyranoside-based species 4 brings about excess of the $(+)-(R)$ enantiomer with ee of $80 \%$. 


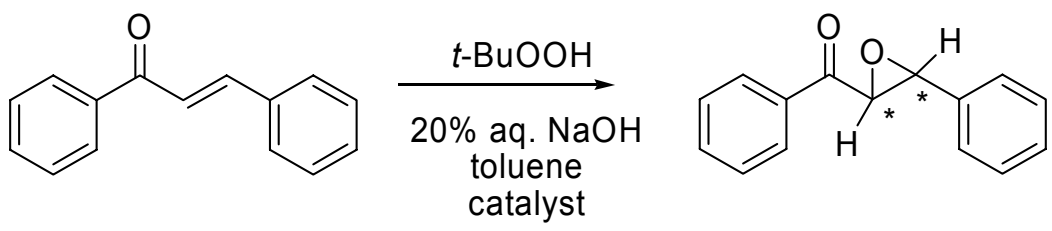

Scheme 4. Asymmetric epoxidation of chalcone.

Chiral macrocycles 1-4 were used as catalyst in the epoxidation of trans chalcone. ${ }^{7}$ In our experiments, the epoxidation of chalcone was carried out with tert-butyl hydroperoxide (TBHP, 2 equiv) at $5^{\circ} \mathrm{C}$, in toluene, in a liquid-liquid two-phase system, employing $20 \%$ aqueous $\mathrm{NaOH}$ (3.5 equiv) as the base and $7 \mathrm{~mol} \%$ of crown ethers having pyridine-ring 1-4 (Scheme 4). The trans-epoxyketone 25 was obtained in all experiments. Table 3 summarizes the results. The epoxidation reaction with these catalysts, however, shows lower enantioselectivity than the Michael addition. The best result of 54\% ee was obtained with the glucopyranoside-based catalyst 1 containing no substituent at the pyridine. The lower enantiomer excess (25\% and $26 \%$ ee) was observed using catalyst $\mathbf{2}$ and $\mathbf{3}$ containing methoxy- and allyloxy groups, respectively. It is worth noting that the crown ether incorporating an glucopyranoside unit (1-3) promoted the formation of the (-)-(2R,3S) isomer of epoxyketone 25 , while the use of mannopyranoside-based ether 4 resulted in the formation of the other, $(+)-(2 S, 3 R)$ enantiomer in $47 \%$ ee.

Table 3. The effect of the crown ether catalysts 1-4 on the enantioselectivity in epoxidation of chalcone at $5^{\circ} \mathrm{C}$

\begin{tabular}{cccccc}
\hline Entry & Catalyst & Time $(\mathrm{h})$ & Yield of $\mathbf{2 5}(\%)^{\mathrm{a}}$ & {$[\alpha]_{\mathrm{D}}{ }^{\mathrm{b}}$} & ee $(\%)^{\mathrm{c}}$ \\
\hline 1 & $\mathbf{1}$ & 9,5 & 38 & -115.5 & $54(2 R, 3 S)$ \\
2 & $\mathbf{2}$ & 8 & 36 & -53.5 & $25(2 R, 3 S)$ \\
3 & $\mathbf{3}$ & 8 & 40 & -55.6 & $26(2 R, 3 S)$ \\
4 & $\mathbf{4}$ & 4.5 & 39 & +100.5 & $47(2 S, 3 R)$ \\
\hline
\end{tabular}

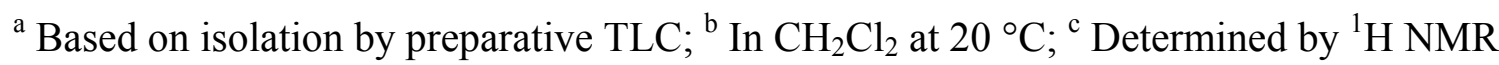
spectroscopy in the presence of $\mathrm{Eu}(\mathrm{hfc})_{3}$ as chiral shift reagent. Absolute configuration were assigned by comparison of specific rotation with literature value ${ }^{7 b}$

The chiral crown compound synthesised could also be tested in other model reactions as phase transfer catalysts. Currently we are investigating the effect of the crown ethers catalysts in other asymmetric reactions. The allylic substituent in compound $\mathbf{3}$ makes possible to bind the macrocycle to a solid carrier (silica gel) allowing the separation study of the racemic mixture of chiral ammonium salts. 


\section{Experimental Section}

General Procedures. All solvents were dried over standard drying agents and freshly distilled. Sodium hydride, used as a mineral oil suspension $(60 \%)$, was washed with dry hexane prior to use. Melting points were taken on using a Büchi 510 apparatus and are uncorrected. Optical rotations were measured with a Perkin-Elmer 241 polarimeter at $20^{\circ} \mathrm{C} .{ }^{1} \mathrm{H}$ and ${ }^{13} \mathrm{C}$ NMR spectra were recorded on a Bruker 300 and a Bruker DRX-500 or a Varian Inova 500 instrument in $\mathrm{CDCl}_{3}$ with TMS as the internal standard. Spectral assignment in the ${ }^{1} \mathrm{H}$ NMR and ${ }^{13} \mathrm{C}$ NMR spectra was carried out based on the 2D correlation diagram HSQC, COSY and NOESY. Mass spectra were registrated from m-nitrobenzyl alcohol (NBA) matrix on a Varian MAT 312 instrument. IR spectra were obtained on a Bruker Tensor 37 FT-IR Spectrometer. Elemental analyses were determined on a Perkin-Elmer 240 automatic analyzer. Analytical and preparative thin layer chromatography was performed on silica gel plates (60 GF-254, Merck), while column chromatography was carried out using 70-230 mesh silica gel (Merck). Chemicals and the shift reagent $\mathrm{Eu}(\mathrm{hfc})_{3}$ were purchased from Aldrich Chem. Co.

The known precursors 5-16 were prepared according to literature procedures. ${ }^{11-15}$ The structure of the known products was confirmed by comparison of their mp-s, analytical and spectral data (MS, ${ }^{1} \mathrm{H}$ NMR) with those reported in the literature. The yield of the compounds was the following: 5 74\% (Lit. ${ }^{12}$ 93\%); 6 87\% (Lit. ${ }^{11}$ 94\%); 7 72\% (Lit. ${ }^{13} 85 \%$ ); 8 83\% (Lit. ${ }^{14} 77 \%$ ); 9 80\% (Lit. ${ }^{15} 80 \%$ ); 10 84\% (Lit. ${ }^{11}$ 86\%); 11 81\% (Lit. ${ }^{11}$ 75\%); 12 79\% (Lit. ${ }^{11} 81 \%$ ); 13 67\% (Lit. ${ }^{11} 77 \%$ ); 14 68\% (Lit. ${ }^{11} 71 \%$ ); 15 62\% (Lit. ${ }^{11} 75 \%$ ); 16 79\% (Lit. ${ }^{11} 71 \%$ )."

\section{General method for the preparation of compounds 18, 22}

A solution of the sugar-derivative 17 or $21(8.0 \mathrm{~g}, 28.4 \mathrm{mmol})$ in dry DMF $(50 \mathrm{~mL})$ was added to a well-stirred suspension of $\mathrm{NaH}(2.88 \mathrm{~g} 120 \mathrm{mmol})$ in dry DMF $(50 \mathrm{~mL})$. After stirring for 30 min at $60{ }^{\circ} \mathrm{C}$ a solution of sodium chloroacetate $(13.2 \mathrm{~g}, 113.6 \mathrm{mmol})$ in dry DMF $(20 \mathrm{~mL})$ was added in small portions. The mixture was heated and stirred at $100{ }^{\circ} \mathrm{C}$ for $40 \mathrm{~h}$. After cooling the mixture was treated with water (6 mL). (TLC eluent toluene-MeOH, 2:1.) DMF was removed by distillation in vacuum. The residue was dissolved in $\mathrm{CHCl}_{3}$ and the precipitate was filtered off (sodium salt of the product). The precipitate was dissolved in water $(250 \mathrm{~mL})$ and extracted with $\mathrm{CHCl}_{3}(3 \times 40 \mathrm{~mL})$. The aqueous phase was cooled to $5{ }^{\circ} \mathrm{C}$ and acidified with aq. $20 \% \mathrm{HCl}$ to $\mathrm{pH}$ 2. The precipitate formed was filtered, dissolved in $\mathrm{CHCl}_{3}$ repeated washed with water, dried $\left(\mathrm{Na}_{2} \mathrm{SO}_{4}\right)$ and evaporated to dryness in vacuo to obtain about $11 \mathrm{~g}$ of raw product, which was crystallized from a mixture of benzene-acetone.

Methyl-4,6- $\boldsymbol{O}$-benzylidene-2,3- $\boldsymbol{O}$-bis(carboxymethyl)- $\alpha$-D-glucopyranoside (18). Yield: 8.82 g $(78 \%)$ white solid. m.p. $135-136^{\circ} \mathrm{C}$. $[\alpha]_{\mathrm{D}}{ }^{20}=+87.9$ (c. $\left.1.0, \mathrm{CHCl}_{3}\right)$. IR $(\mathrm{KBr}): 3444\left(\mathrm{sbr}, v_{\mathrm{OH}}\right.$

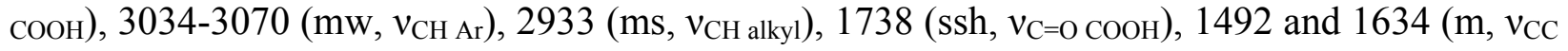
$\mathrm{Ar}), 1455\left(\mathrm{~m}, \delta_{\mathrm{CCH}}, \delta_{\mathrm{OCH}}\right), 1384\left(\mathrm{~ms}, \delta_{\mathrm{OCH}}\right), 1217-1317\left(\mathrm{mw}, v_{\mathrm{CO}}, \delta_{\mathrm{CCH}}, \delta_{\mathrm{COH}}\right), 1198\left(\mathrm{mw}, \delta_{\mathrm{OCH}}\right.$, $\left.\delta_{\mathrm{CCH}}\right), 922-1180\left(\mathrm{~s}, v_{\mathrm{CO}}, v_{\mathrm{CC}}\right), 702$ and $755\left(\mathrm{msh}, \gamma_{\mathrm{CC}}, \gamma_{\mathrm{CH}}\right) \mathrm{cm}^{-1} .{ }^{1} \mathrm{H} \mathrm{NMR}\left(500 \mathrm{MHz}, \mathrm{CDCl}_{3}\right) \delta$ : 
3.44 (s, 3H, $\left.\mathrm{OCH}_{3}\right), 3.56-3.94$ (m, 5H, H-2, H-3, H-4, H-5, H-6), 4.29 (dd, J=4.6, $10.1 \mathrm{~Hz}, 1 \mathrm{H}$, H-6), 4.27-4.57 (m, 4H, CH $\left.\mathrm{C}_{2} \mathrm{COOH}\right), 4.89$ (d, $\left.J=3.6 \mathrm{~Hz}, 1 \mathrm{H}, \mathrm{H}-1\right), 5.51$ (s, 1H, CH-Ph), 7.37 (t, $2 \mathrm{H}, \mathrm{PhH}-m), 7.38$ (t, 1H, PhH-p), 7,44 (d, 2H, PhH-o). ${ }^{13} \mathrm{C}$ NMR $\left(75 \mathrm{MHz}, \mathrm{CDCl}_{3}\right) \delta: 55.35$ $\left(\mathrm{OCH}_{3}\right), 61.95(\mathrm{C}-5), 68.93,69.16\left(2 \mathrm{CH}_{2} \mathrm{COOH}\right), 69.61$ (C-6), 79.81 (C-3), 81.27 (C-2), 81.70 (C-4), 98.36 (C-1), 101.66 (CH-Ph), 126.03 (2×PhC-o), 128.37 (2×PhC-m), 129.24 (PhC-p), 136.82 (PhC-ipso), $175.49(2 \times \mathrm{COOH})$. FAB-MS: $399[\mathrm{M}+\mathrm{H}]^{+}, 421[\mathrm{M}+\mathrm{Na}]^{+}$. HRMS: $m / z$ $[\mathrm{M}]^{+}$calcd for $\mathrm{C}_{18} \mathrm{H}_{22} \mathrm{O}_{10}: 398.1213$; found: 398.1218. Anal. Calcd. for $\mathrm{C}_{18} \mathrm{H}_{22} \mathrm{O}_{10}$ : C, 54.27 ; $\mathrm{H}$, $5.57 \%$. Found: C, 54.29; H, $5.60 \%$.

Methyl-4,6- $\boldsymbol{O}$-benzylidene-2,3- $\boldsymbol{O}$-bis(carboxymethyl)- $\boldsymbol{\alpha}$-D-mannopyranoside (22). Yield: 8.6 g (76 \%). m.p. $146-147^{\circ} \mathrm{C}$. $[\alpha]_{\mathrm{D}}{ }^{20}=+10.0$ (c. 1.0, $\left.\mathrm{CHCl}_{3}\right)$. IR (KBr): 3448 (sbr, $\left.v_{\mathrm{OH} \mathrm{COOH}}\right), 3037-$ $3067\left(\mathrm{mw}, v_{\mathrm{CH} \mathrm{Ar}}\right), 2929\left(\mathrm{~ms}, v_{\mathrm{CH} \text { alkyl }}\right), 1733$ (ssh, $\left.v_{\mathrm{C}=\mathrm{O} \text { СOOH}}\right), 1498$ and 1635 (m, $\left.v_{\mathrm{CC} \mathrm{Ar}}\right), 1417$ and $1452\left(\mathrm{~m}, \delta_{\mathrm{CCH}}, \delta_{\mathrm{OCH}}\right), 1384\left(\mathrm{~ms}, \delta_{\mathrm{OCH}}\right), 1220-1317\left(\mathrm{mw}, v_{\mathrm{CO}}, \delta_{\mathrm{CCH}}, \delta_{\mathrm{COH}}\right), 1175\left(\mathrm{mw}, \delta_{\mathrm{OCH}}\right.$, $\left.\delta_{\mathrm{CCH}}\right), 915-1175\left(\mathrm{~s}, v_{\mathrm{CO}}, v_{\mathrm{CC}}\right), 701$ and $754\left(\mathrm{msh}, \gamma_{\mathrm{CC}}, \gamma_{\mathrm{CH}}\right) \mathrm{cm}^{-1} .{ }^{1} \mathrm{H} \mathrm{NMR}\left(500 \mathrm{MHz}, \mathrm{CDCl}_{3}\right) \delta$ : $3.39\left(\mathrm{~s}, 3 \mathrm{H}, \mathrm{OCH}_{3}\right), 3.80-4.27(\mathrm{~m}, 6 \mathrm{H}, \mathrm{H}-2, \mathrm{H}-3, \mathrm{H}-4, \mathrm{H}-5,2$ x H-6) 4.30-4.39 (m, 4H, $\left.\mathrm{CH}_{2} \mathrm{COOH}\right), 4.78$ (d, J=1.3 Hz, 1H, H-1), 5.55 (s, 1H, CH-Ph), 7.36 (t, 2H, PhH-m), 7.38 (t, 1H, $\mathrm{PhH}-p), 7,44$ (d, 2H, PhH-o). ${ }^{13} \mathrm{C} \mathrm{NMR}\left(75 \mathrm{MHz}, \mathrm{CDCl}_{3}\right) \delta: 55.09\left(\mathrm{OCH}_{3}\right), 63.63(\mathrm{C}-5), 67.55$ $\left(\mathrm{CH}_{2} \mathrm{COOH}\right), 68.50(\mathrm{C}-6), 69.21,\left(\mathrm{CH}_{2} \mathrm{COOH}\right), 78.69$ (C-3), $78.86(\mathrm{C}-4), 79.18(\mathrm{C}-2), 98.72(\mathrm{C}-$ 1), 101.57 (CH-Ph), 125.95 (2×PhC-o), 128.38 (2×PhC-m), 129.17 (PhC-p), 137.03 (PhC-ipso), $173.62(2 \mathrm{xCOOH}), 174.22(\mathrm{COOH}) . \mathrm{FAB}-\mathrm{MS}: 399[\mathrm{M}+\mathrm{H}]^{+}, 421[\mathrm{M}+\mathrm{Na}]^{+}$. HRMS: $m / z$ $[\mathrm{M}]^{+}$calcd for $\mathrm{C}_{18} \mathrm{H}_{22} \mathrm{O}_{10}: 398.1213$; found: 398.1222. Anal. Calcd. for $\mathrm{C}_{18} \mathrm{H}_{22} \mathrm{O}_{10}: \mathrm{C}, 54.27$; $\mathrm{H}$, $5.57 \%$. Found: C, 54.39; H, $5.53 \%$.

\section{General method for the preparation of compounds 19, 23}

A solution of the carboxylic acid 18 or $22(4.0 \mathrm{~g}, 10 \mathrm{mmol})$ in THF $(10 \mathrm{~mL})$ was slowly added to a suspension of $\mathrm{NaBH}_{4}(1.13 \mathrm{~g}, 30 \mathrm{mmol})$ in THF $(10 \mathrm{~mL})$ at room temperature $(10 \mathrm{~min})$. The mixture was stirred until evolution of gas ceases. Iodine $(3.18 \mathrm{~g}, 12.5 \mathrm{mmol})$ in THF $(15 \mathrm{~mL})$ was added slowly (10 min) and additional hydrogen evolved. The contents were further stirred for $5 \mathrm{~h}$. (TLC eluent toluene-MeOH, 10:2.) Dilute $\mathrm{HCl}(13 \mathrm{~mL}, 3 \mathrm{~N})$ was added carefully and the mixture was extracted with ether. The combined ether extract was washed with $3 \mathrm{~N} \mathrm{NaOH}(3 \times 25$ $\mathrm{mL})$, brine and dried $\left(\mathrm{MgSO}_{4}\right)$. Evaporation of the organic layer gave the alcohol product, which was purified by column chromatography on silica gel using $2 \%$ to $5 \% \mathrm{MeOH}$ in $\mathrm{CHCl}_{3}$ as the eluant.

Methyl-4,6- $\boldsymbol{O}$-benzylidene-2,3- $\boldsymbol{O}$-bis(2-hydroxyethyl)- $\alpha$ - $\boldsymbol{D}$-glucopyranoside (19). Yield: 2.96 g $(80 \%)$. m.p. $111-114{ }^{\circ} \mathrm{C} .[\alpha]_{\mathrm{D}}{ }^{20}=+71.8$ (c. 1.0, $\left.\mathrm{CHCl}_{3}\right)$. IR (KBr): 3393 and 3499 (sbr, $\left.v_{\mathrm{OH}}\right)$,

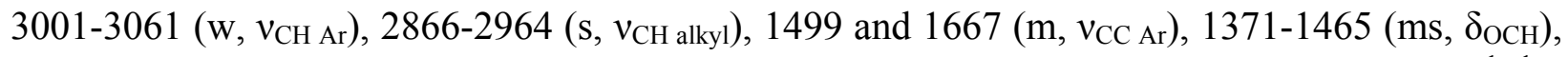
1213-1330 (mw, $\left.v_{\mathrm{CO}}, \delta_{\mathrm{CCH}}, \delta_{\mathrm{COH}}\right), 905-1194\left(\mathrm{~s}, v_{\mathrm{CO}}, v_{\mathrm{CC}}\right), 695$ and $743\left(\mathrm{mssh}, \gamma_{\mathrm{CC}}, \gamma_{\mathrm{CH}}\right) \mathrm{cm}^{-1} .{ }^{1} \mathrm{H}$ NMR (500 MHz, $\left.\mathrm{CDCl}_{3}\right) \delta: 3.43\left(\mathrm{~s}, 3 \mathrm{H}, \mathrm{OCH}_{3}\right), 3.51-3.57$ (m, 2H, H-2, H-4), 3.68-3.74 (m, 5H, $\left.2 \times \mathrm{OCH}_{2}, \mathrm{H}-6\right), 3.80$ (dd, $\left.J=4.5,10.0 \mathrm{~Hz}, 1 \mathrm{H}, \mathrm{H}-5\right), 3.81-3.94$ (m, 4H, 2 x OCH ), 4.28 (dd, $J$ $=4.5,10.0 \mathrm{~Hz}, 1 \mathrm{H}, \mathrm{H}-6), 4.85(\mathrm{~d}, J=3.5 \mathrm{~Hz}, 1 \mathrm{H}, \mathrm{H}-1), 5.54(\mathrm{~s}, 1 \mathrm{H}, \mathrm{CH}-\mathrm{Ph}), 7.36(\mathrm{t}, 2 \mathrm{H}, \mathrm{PhH}-$ $m), 7.37$ (t, 1H, PhH-p), 7,47 (d, 2H, PhH-o). ${ }^{13} \mathrm{C}$ NMR (125 MHz, $\left.\mathrm{CDCl}_{3}\right) \delta: 55.15\left(\mathrm{OCH}_{3}\right)$, 
61.55, $61.70\left(2 \mathrm{CH}_{2} \mathrm{OH}\right), 62.24(\mathrm{C}-5), 68.85(\mathrm{C}-6), 72.74,74.34\left(2 \mathrm{OCH}_{2}\right), 77.85(\mathrm{C}-3), 80.18$ (C-2), 81.77 (C-4), 98.25 (C-1), 101.38 (CH-Ph), $125.90(2 \times$ PhC-o), 128.18 (2 × PhC-m), 128.99 (PhC-p), 136.95 (PhC-ipso). FAB-MS: $371[\mathrm{M}+\mathrm{H}]^{+}, 393[\mathrm{M}+\mathrm{Na}]^{+}$. HRMS: $m / z[\mathrm{M}]^{+}$ calcd for $\mathrm{C}_{18} \mathrm{H}_{26} \mathrm{O}_{8}: 370.1628$; found: 370.1633. Anal. Calcd. for $\mathrm{C}_{18} \mathrm{H}_{26} \mathrm{O}_{8}: \mathrm{C}, 58.37$; H, $7.08 \%$. Found: C, 58.34; H, $7.06 \%$.

Methyl-4,6- $O$-benzylidene-2,3- $O$-bis(2-hydroxyethyl)- $\alpha$ - $D$-mannopyranoside $\quad(23)$ Yield: 2.52 g $\left(68 \%\right.$ ). m.p. $91-92{ }^{\circ} \mathrm{C} .[\alpha]_{\mathrm{D}}{ }^{20}=+6.4$ (c. 1.0, $\left.\mathrm{CHCl}_{3}\right)$. IR (neat): 3421 (sbr, $\left.v_{\mathrm{OH}}\right), 3037-$ $3067\left(\mathrm{w}, v_{\mathrm{CH} \mathrm{Ar}}\right), 2874-2916\left(\mathrm{~s}, v_{\mathrm{CH} \text { alkyl }}\right), 1493$ and $1639\left(\mathrm{~m}, v_{\mathrm{CC} \mathrm{Ar}}\right), 1378-1456\left(\mathrm{~ms}, \delta_{\mathrm{OCH}}\right), 1217-$ $1318\left(\mathrm{~m}, v_{\mathrm{CO}}, \delta_{\mathrm{CCH}}, \delta_{\mathrm{COH}}\right), 1200\left(\mathrm{mw}, \delta_{\mathrm{OCH}}, \delta_{\mathrm{CCH}}\right), 976-1175\left(\mathrm{~s}, v_{\mathrm{CO}}, v_{\mathrm{CC}}\right), 700$ and 756, (mssh, $\left.\gamma_{\mathrm{CC}}, \gamma_{\mathrm{CH}}\right) \mathrm{cm}^{-1} .{ }^{1} \mathrm{H}$ NMR $\left(500 \mathrm{MHz}, \mathrm{CDCl}_{3}\right) \delta: 2.02(\mathrm{bs}, 1 \mathrm{H}, \mathrm{OH}), 3.18$ (bs, $\left.1 \mathrm{H}, \mathrm{OH}\right), 3.39(\mathrm{~s}, 3 \mathrm{H}$, $\left.\mathrm{OCH}_{3}\right), 3.63-3.85\left(\mathrm{~m}, 10 \mathrm{H}, 4\right.$ x $\mathrm{OCH}_{2}, 2$ x CH), 3.87 (d, $\left.J=3.7 \mathrm{~Hz}, 1 \mathrm{H}, \mathrm{H}-3\right), 3.93-4.08$ (m, 2H, $2 \times \mathrm{CH}), 4.26(\mathrm{dd}, J=4.5,10.0 \mathrm{~Hz}, 1 \mathrm{H}, \mathrm{H}-6), 4.74(\mathrm{~d}, J=1.3 \mathrm{~Hz}, 1 \mathrm{H}, \mathrm{H}-1), 5.60$ (s, 1H, CH$\mathrm{Ph}), 7.36$ (t, 2H, PhH-m), 7.37 (t, 1H, PhH-p), 7,46 (d, 2H, PhH-o). ${ }^{13} \mathrm{C}$ NMR $\left(125 \mathrm{MHz}, \mathrm{CDCl}_{3}\right)$ $\delta$ : $54.90\left(\mathrm{OCH}_{3}\right), 61.23,61.86\left(2 \mathrm{CH}_{2} \mathrm{OH}\right), 63.67(\mathrm{C}-5), 68.71(\mathrm{C}-6), 73.43,73.47\left(2 \mathrm{OCH}_{2}\right.$ of the podand arm), 76.83 (C-3), 78.21 (C-2), 78.81 (C-4), 100.13 (C-1), 101.75 (CH-Ph), 125.97 (2 $\times$ PhC-o), 128.24 (2 × PhC-m), 129.04 (PhC-p), 137.16 (PhC-ipso). FAB-MS: $371[\mathrm{M}+\mathrm{H}]^{+}$, $393[\mathrm{M}+\mathrm{Na}]^{+}$. HRMS: $m / z[\mathrm{M}]^{+}$calcd for $\mathrm{C}_{18} \mathrm{H}_{26} \mathrm{O}_{8}: 370.1628$; found: 370.1634. Anal. Calcd. for $\mathrm{C}_{18} \mathrm{H}_{26} \mathrm{O}_{8}$ : C, 58,37; H, 7,08 \%. Found: C, 58.43; H, $7.05 \%$.

\section{Methyl-4,6- $O$-benzylidene-2,3- $O$-bis(p-toluenesulphonyloxyethyl)- $\alpha$ - $D$-glucopyrano-side}

(20). A mixture of diol 19 (2.0 g, $5.4 \mathrm{mmol}), \mathrm{NaOH}$ solution (1.0 g, $25 \mathrm{mmol}$ in $8 \mathrm{~mL}$ water), THF $(8 \mathrm{~mL})$ was stirred for $10 \mathrm{~min}$ at RT. The reaction mixture was cooled to $0{ }^{\circ} \mathrm{C}$. A solution of p-toluenesulfonyl chloride $(2.17 \mathrm{~g}, 11.4 \mathrm{mmol})$ in THF $(12 \mathrm{~mL})$ was added dropwise so that the temperature was kept below $5{ }^{\circ} \mathrm{C}$. The reaction mixture was stirred at $0-5{ }^{\circ} \mathrm{C}$ for $12 \mathrm{~h}$, then was poured into water $(50 \mathrm{~mL})$ and extracted with $\mathrm{CH}_{2} \mathrm{Cl}_{2}(3 \times 50 \mathrm{~mL})$. The combined organic extracts were dried $\left(\mathrm{Na}_{2} \mathrm{SO}_{4}\right)$ and concentrated in vacuo. The product was purified by column chromatography (silica gel; $\mathrm{CH}_{2} \mathrm{Cl}_{2}-\mathrm{MeOH}, 100: 2$ ) furnished 20 as a white solid material. Yield: 2.45 g, $(67 \%)$. m.p. $121-122^{\circ} \mathrm{C}$. $[\alpha]_{\mathrm{D}}{ }^{20}=+28.0$ (c. $\left.1.0, \mathrm{CHCl}_{3}\right) .{ }^{1} \mathrm{H}$ NMR $\left(500 \mathrm{MHz}, \mathrm{CDCl}_{3}\right) \delta$ : 2.42 and $2,44\left(\mathrm{~s}, 3 \mathrm{H}, 2 \times \mathrm{CH}_{3}\right), 3.35(\mathrm{dd}, J=3.7,9.3 \mathrm{~Hz}, 1 \mathrm{H}, \mathrm{H}-2), 3.39\left(\mathrm{~s}, 3 \mathrm{H}, \mathrm{OCH}_{3}\right), 3.44(\mathrm{~d}, J$ $=9.1 \mathrm{~Hz}, 1 \mathrm{H}, \mathrm{H}-4), 3.70-4.14\left(\mathrm{~m}, 11 \mathrm{H}, 4 \mathrm{x} \mathrm{CH}_{2}, \mathrm{H}-3, \mathrm{H}-5\right.$ and H-6), $4.26(\mathrm{dd}, J=4.0,9.4 \mathrm{~Hz}$, 1H, H-6), 4.75 (d, $J=3.7 \mathrm{~Hz}, 1 \mathrm{H}, \mathrm{H}-1), 5.48$ (s, 1H, CH-Ph), 7.28-7.80 (m, 13H, ArH). ${ }^{13} \mathrm{C}$ NMR (75 MHz, $\left.\mathrm{CDCl}_{3}\right) \delta:$ 21.50, $21.53\left(2 \mathrm{xCH}_{3}\right), 55.25\left(\mathrm{OCH}_{3}\right), 62.02(\mathrm{C}-5), 68.90(\mathrm{C}-6), 69.32$, $69.59,69.98,70.10\left(4 \mathrm{OCH}_{2}\right.$ of the podand arm), 79.25 (C-3), 80.19 (C-2), 81.81 (C-4), 98.85 (C-1), 101.18 (CH-Ph), 125.91 ( $2 \times \mathrm{PhC}-\mathrm{o}), 127.78-127.84$ (4 x ArC), 128.15 (2 × PhC-m), 128.88 (PhC-p), 129.72-132.97(6 x ArC), 137.12 (PhC-ipso), 144.66-144.80 (2 x ArC). FABMS: $679[\mathrm{M}+\mathrm{H}]^{+}, 701[\mathrm{M}+\mathrm{Na}]^{+}$. HRMS: $m / z[\mathrm{M}]^{+}$calcd for $\mathrm{C}_{32} \mathrm{H}_{38} \mathrm{O}_{12} \mathrm{~S}_{2}$ : 678.1805 ; found: 678.1797. Anal. Calcd. for $\mathrm{C}_{32} \mathrm{H}_{38} \mathrm{O}_{12} \mathrm{~S}_{2}$ : C, 56.62; H, $5.64 \%$. Found: C, 56.66; H, $5.65 \%$.

\section{General method for the preparation of crown ethers 1- 4 (Method B)}

A solution of diol 19 or $23(0.6 \mathrm{~g}, 1.6 \mathrm{mmol})$ in dry DMF $(10 \mathrm{~mL})$ was added slowly to a well stirred suspension of $\mathrm{NaH}(0.19 \mathrm{~g}, 8 \mathrm{mmol})$ in $\mathrm{DMF}(10 \mathrm{~mL})$ under Ar and stirred at $60{ }^{\circ} \mathrm{C}$ for 30 
min. To the mixture, a solution of the appropriate tosylate $(\mathbf{6}, 14$ or 16) $(1.6 \mathrm{mmol})$ in dry DMF $(10 \mathrm{~mL})$ was added and the mixture was stirred at $60^{\circ} \mathrm{C}$ for further $40 \mathrm{~h}$. After cooling to RT, excess $\mathrm{NaH}$ was destroyed by the dropwise addition of water. The solvent was removed, the residue was taken up in the mixture of water $(40 \mathrm{~mL})$ and $\mathrm{CH}_{2} \mathrm{Cl}_{2}(40 \mathrm{~mL})$. The aqueous phase was shaken with $\mathrm{CH}_{2} \mathrm{Cl}_{2}(3 \times 40 \mathrm{~mL})$. The combined organic phase was dried $\left(\mathrm{Na}_{2} \mathrm{SO}_{4}\right)$ and evaporated in vacuum. The crude product was purified by column chromatography on neutral alumina using 1-5\% $\mathrm{MeOH}$ in $\mathrm{CHCl}_{3}$ as an eluent to give pure 1, 2, $\mathbf{3}$ and $\mathbf{4}$ as a solid.

Chiral crown ether 1. Yield: $0.30 \mathrm{~g}(40 \%)$. m.p. $147-148^{\circ} \mathrm{C} .[\alpha]_{\mathrm{D}}{ }^{20}=+23.5$ (c. $\left.1.0, \mathrm{CHCl}_{3}\right) .{ }^{1} \mathrm{H}$ NMR (500 MHz, $\left.\mathrm{CDCl}_{3}\right) \delta: 3.45\left(\mathrm{~s}, 3 \mathrm{H}, \mathrm{OCH}_{3}\right), 3.53-3.59(\mathrm{~m}, 2 \mathrm{H}, \mathrm{H}-2, \mathrm{H}-4), 3.63-3.66(\mathrm{~m}, 4 \mathrm{H}$, $\left.2 \mathrm{x} \mathrm{OCH}_{2}\right), 3.74-3.85$ (m, 3H, H-3, H-5, H-6), 3.87- 4.05 (m, 4H, OCH$), 4.29$ (dd, J=4.6, 10.0 $\mathrm{Hz}, 1 \mathrm{H}, \mathrm{H}-6), 4.52-4.57$ (m, 4H, Ar- $\left.\mathrm{CH}_{2}\right), 4.87$ (d, J=3.6 Hz, 1H, H-1), 5.55 (s, 1H, CH-Ph), 7.20 (d, $J=7.7 \mathrm{~Hz}, 1 \mathrm{H}$, pyrH-3), 7.27 (d, $J=7.6 \mathrm{~Hz}, 1 \mathrm{H}$, pyrH-5), 7.36 (t, 1H, PhH-p), 7,37 (t, $2 \mathrm{H}, \mathrm{PhH}-m), 7.49$ (d, 1H, PhH-o), $7.50(\mathrm{t}, 1 \mathrm{H}, \mathrm{pyrH}-4) .{ }^{13} \mathrm{C} \mathrm{NMR}\left(125 \mathrm{MHz}, \mathrm{CDCl}_{3}\right) \delta: 55.26$ $\left(\mathrm{OCH}_{3}\right), 62.25(\mathrm{C}-5), 69.08(\mathrm{C}-6), 70.07,70.49,71.03,72.42\left(4 \mathrm{x} \mathrm{OCH}_{2}\right.$ of the macrocycle), 73.72, $73.85\left(\mathrm{Ar}-\mathrm{CH}_{2}\right), 78.98$ (C-3), 80.18 (C-2), 82.15 (C-4), 98.90 (C-1), 101.28 (CH-Ph), 119.44, 119.87 (pyrC-3,5), 126.02 (2 × PhC-o), 126.03 (pyrC-4), $128.21(2 \times \mathrm{PhC}-\mathrm{m}), 128.91$ (PhC-p), 137.40 (PhC-ipso), 157.80, 157.81 (pyrC-2,6). FAB-MS: $496[\mathrm{M}+\mathrm{Na}]^{+}$. HRMS: $m / z$ $[\mathrm{M}]^{+}$calcd for $\mathrm{C}_{25} \mathrm{H}_{31} \mathrm{NO}_{8}$ : 473.2050; found: 473.2053. Anal. Calcd. for $\mathrm{C}_{25} \mathrm{H}_{31} \mathrm{NO}_{8}$ : C, 63.41; H, $6.60 \%$. Found: C, 63.44; H, $6.58 \%$.

Chiral crown ether 2. Yield: $0.23 \mathrm{~g}(29 \%)$. m.p. $142-145{ }^{\circ} \mathrm{C} .[\alpha]_{\mathrm{D}}{ }^{20}=+26.4$ (c. $\left.1.0, \mathrm{CHCl}_{3}\right) .{ }^{1} \mathrm{H}$ NMR (500 MHz, $\left.\mathrm{CDCl}_{3}\right) \delta: 3.44\left(\mathrm{~s}, 3 \mathrm{H}, \mathrm{OCH}_{3}\right), 3.52-3.58(\mathrm{~m}, 2 \mathrm{H}, \mathrm{H}-2, \mathrm{H}-4), 3.63-3.66(\mathrm{~m}, 4 \mathrm{H}$, $\mathrm{OCH}_{2}$ of the macrocycle), $3.73(\mathrm{t}, J=10.0 \mathrm{~Hz}, 1 \mathrm{H}, \mathrm{H}-6), 3.79\left(\mathrm{~s}, 3 \mathrm{H}, \mathrm{pyr}-\mathrm{OCH}_{3}\right), 3.82(\mathrm{dd}, J=$ $4.8,9.2 \mathrm{~Hz}, 1 \mathrm{H}, \mathrm{H}-5), 3.84(\mathrm{t}, J=9.2 \mathrm{~Hz}, 1 \mathrm{H}, \mathrm{H}-3), 3.87-4.03\left(\mathrm{~m}, 4 \mathrm{H}, \mathrm{OCH}_{2}\right.$ of the macrocycle), 4.29 (dd, $J=4.7,10.0 \mathrm{~Hz}, 1 \mathrm{H}, \mathrm{H}-6), 4.46-4.54$ (m, 4H, Ar- $\left.\mathrm{CH}_{2}\right), 4.86$ (d, J=3.6 Hz, 1H, H-1), 5.54 (s, 1H, CH-Ph), 6.73 (s, 1H, pyrH-3), 6.77 (s, 1H, pyrH-5), 7,35 (t, 2H, PhH-m), 7.36 (t, 1H,

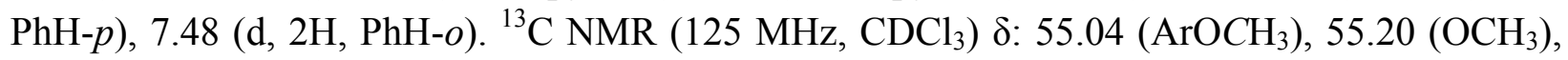
62.20 (C-5), 69.04 (C-6), 70.04, 70.42, 71.00, 72.40 (4 $\mathrm{OCH}_{2}$ of the macrocycle), 73.45, 73.53 $\left(\mathrm{Ar}-\mathrm{CH}_{2}\right), 78.87$ (C-3), 80.17 (C-2), 82.10 (C-4), 98.82 (C-1), 101.23 (CH-Ph), 105.29, 105.61 (pyrC-3,5), $125.98(2 \times \mathrm{PhC}-\mathrm{o}), 128.17$ (2 × PhC-m), 128.86 (PhC-p), 137.35 (PhC-ipso), 159.53, 157.60 (pyrC-2,6), 166.93 (pyrC-4). FAB-MS: $526[\mathrm{M}+\mathrm{Na}]^{+}$. HRMS: $m / z[\mathrm{M}]^{+}$calcd for $\mathrm{C}_{26} \mathrm{H}_{33} \mathrm{NO}_{9}$ : 503.2155; found: 503.2164. Anal. Calcd. for $\mathrm{C}_{26} \mathrm{H}_{33} \mathrm{NO}_{9}$ : C, 62,02; $\mathrm{H}, 6,61 \%$. Found: C, 62.07; H, $6.57 \%$.

Chiral crown ether 3. Yield: $0.28 \mathrm{~g}(33 \%)$. m.p. $129-131{ }^{\circ} \mathrm{C}[\alpha]_{\mathrm{D}}{ }^{20}=+27.8\left(\right.$ c. $\left.1.0, \mathrm{CHCl}_{3}\right) .{ }^{1} \mathrm{H}$ NMR (500 MHz, $\left.\mathrm{CDCl}_{3}\right) \delta: 3.44\left(\mathrm{~s}, 3 \mathrm{H}, \mathrm{OCH}_{3}\right), 3.52-3.58(\mathrm{~m}, 2 \mathrm{H}, \mathrm{H}-2, \mathrm{H}-4), 3.63-3.65(\mathrm{~m}, 4 \mathrm{H}$, $\mathrm{OCH}_{2}$ of the macrocycle), $3.73(\mathrm{t}, J=10.1 \mathrm{~Hz}, 1 \mathrm{H}, \mathrm{H}-6), 3.81$ (dd, $\left.J=4.6,9.3 \mathrm{~Hz}, 1 \mathrm{H}, \mathrm{H}-5\right)$, $3.83(\mathrm{t}, J=9.4 \mathrm{~Hz}, 1 \mathrm{H}, \mathrm{H}-3), 3.85-4.04\left(\mathrm{~m}, 4 \mathrm{H}, 2 \mathrm{xOCH}_{2}\right.$ of the macrocycle), 4.28 (dd, $J=4.6$, $9.9 \mathrm{~Hz}, 1 \mathrm{H}, \mathrm{H}-6), 4.46,4.53\left(\mathrm{dd}, 4 \mathrm{H}, J=15.0 \mathrm{~Hz}, \mathrm{Ar}-\mathrm{CH}_{2}\right), 4.49(\mathrm{~d}, J=4.7 \mathrm{~Hz}, 2 \mathrm{H}$, $\left.\mathrm{OCH}_{2} \mathrm{CHCH}_{2}\right), 4.86(\mathrm{~d}, J=3.3 \mathrm{~Hz}, 1 \mathrm{H}, \mathrm{H}-1), 5.28-5.40\left(\mathrm{~m}, 2 \mathrm{H}, \mathrm{OCH}_{2} \mathrm{CHCH}_{2}\right), 5.54(\mathrm{~s}, 1 \mathrm{H}, \mathrm{CH}-$ $\mathrm{Ph}), 6,00\left(\mathrm{~m}, 1 \mathrm{H}, \mathrm{OCH}_{2} \mathrm{CHCH}_{2}\right), 6.74(\mathrm{~s}, 1 \mathrm{H}, \mathrm{pyrH}), 6.78(\mathrm{~s}, 1 \mathrm{H}, \mathrm{pyrH}), 7,35$ (t, 2H, PhH- $m$ ),

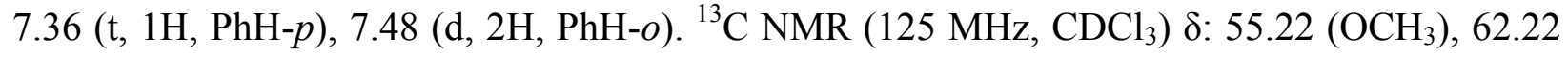


(C-5), $68.39\left(\mathrm{OCH}_{2} \mathrm{CH}=\mathrm{CH}_{2}\right), 69.04(\mathrm{C}-6), 70.05,70.40,70.96,72.43\left(4 \times \mathrm{OCH}_{2}\right.$ of the macrocycle), 73.40, 73.51 ( $\left.\mathrm{Ar}-\mathrm{CH}_{2}\right), 78.85$ (C-3), 80.17 (C-2), 82.09 (C-4), 98.80 (C-1), 101.23 $(\mathrm{CH}-\mathrm{Ph}), 105.85,106.12$ (pyrC-3,5), $118.18\left(\mathrm{OCH}_{2} \mathrm{CH}=\mathrm{CH}_{2}\right), 125.99(2 \times \mathrm{PhC}-\mathrm{o}), 128.17(2 \times$ PhC-m), 128.87 (PhC-p), $132.27\left(\mathrm{OCH}_{2} \mathrm{CH}=\mathrm{CH}_{2}\right), 137.36$ (PhC-ipso), 159.59, 159.68 (pyrC2,6), 165.91 (pyrC-4). FAB-MS: $552[\mathrm{M}+\mathrm{Na}]^{+}$. HRMS: $\mathrm{m} / z[\mathrm{M}]^{+}$calcd for $\mathrm{C}_{28} \mathrm{H}_{35} \mathrm{NO}_{9}$ : 529.2312; found: 529.2322 .

Anal. Calcd. for $\mathrm{C}_{28} \mathrm{H}_{35} \mathrm{NO}_{9}$ : C, 63.50; H, $6.66 \%$. Found: C, 63.47; H, $6.62 \%$.

Chiral crown ether 4. Yield: $0.16 \mathrm{~g}(21 \%)$. m.p. $134-136^{\circ} \mathrm{C} .[\alpha]_{\mathrm{D}}{ }^{20}=+32.5\left(\right.$ c. $\left.1.0, \mathrm{CHCl}_{3}\right) .{ }^{1} \mathrm{H}$ $\operatorname{NMR}\left(500 \mathrm{MHz}, \mathrm{CDCl}_{3}\right) \delta: 3.35\left(\mathrm{~s}, 3 \mathrm{H}, \mathrm{OCH}_{3}\right), 3.62-3.76\left(\mathrm{~m}, 4 \mathrm{H}, \mathrm{OCH}_{2}\right.$ of the macrocycle), 3.78-3.88 (m, 4H, H-2, H-3, H-5, H-6), 3.97-4.07 (m, 4H, $\mathrm{OCH}_{2}$ of the macrocycle), 4.09 (d, $J=$ $9.4 \mathrm{~Hz}, 1 \mathrm{H}, \mathrm{H}-4), 4.21$ (dd, $J=4.7,10.1 \mathrm{~Hz}, 1 \mathrm{H}, \mathrm{H}-6), 4.57-4.66$ (m, 4H, Ar-CH 2$), 4.75$ (d, $J=$ $1.3 \mathrm{~Hz}, 1 \mathrm{H}, \mathrm{H}-1), 5.59$ (s, $1 \mathrm{H}, \mathrm{CH}-\mathrm{Ph}), 7.17$ (d, $J=7.7 \mathrm{~Hz}, 1 \mathrm{H}, \mathrm{pyrH}-3), 7.20(\mathrm{~d}, J=7.6 \mathrm{~Hz}, 1 \mathrm{H}$, pyrH-5), 7.33 (t, 1H, PhH- $p$ ), 7,35 (t, 2H, PhH- $m$ ), 7.46 (d, 2H, PhH-o), 7.65 (t, 1H, pyrH-4) ${ }^{13} \mathrm{C}$ NMR (125 MHz, $\left.\mathrm{CDCl}_{3}\right) \delta: 54.86\left(\mathrm{OCH}_{3}\right), 63.78(\mathrm{C}-5), 68.85$ (C-6), 70.16, 70.68, 71.43, 72.09 (4 x $\mathrm{OCH}_{2}$ of the macrocycle), 73.13, $74.42\left(\mathrm{Ar}-\mathrm{CH}_{2}\right), 77.21$ (C-3), 78.32 (C-2), 79.54 (C-4), 100.54 (C-1), 101.37 (CH-Ph), 122.07, 122.23 (pyrC-3,5), 126.01 (2 $\times$ PhC-o), 128.14 (2 × PhCm), 128.28 (pyrC-4), 128.75 (PhC-p), 137.72 (PhC-ipso), 157.49, 158.23 (pyrC-2,6). FAB-MS: $496[\mathrm{M}+\mathrm{Na}]^{+}$. HRMS: $m / z[\mathrm{M}]^{+}$calcd for $\mathrm{C}_{25} \mathrm{H}_{31} \mathrm{NO}_{8}: 473.2050$; found: 473.2059. Anal. Calcd. for $\mathrm{C}_{25} \mathrm{H}_{31} \mathrm{NO}_{8}$ : $\mathrm{C}, 63.41 ; \mathrm{H}, 6.60 \%$. Found: $\mathrm{C}, 63.52 ; \mathrm{H}, 6.59 \%$.

\section{General procedure for the Michael addition of 2-nitropropane to chalcones ${ }^{6}$}

The corresponding azacrown ether catalyst $(0.1 \mathrm{mmol})$ and sodium tert-butoxide $(0.05 \mathrm{~g}, 0.5$ $\mathrm{mmol})$ was added to a solution of chalcone $(0.3 \mathrm{~g}, 1.44 \mathrm{mmol})$ and 2-nitropropane $(0.3 \mathrm{ml}, 3.36$ $\mathrm{mmol})$ in dry toluene $(3 \mathrm{~mL})$. The mixture was stirred at RT under argon. After a reaction time of 24 to $30 \mathrm{~h}$, a new portion of toluene $(7 \mathrm{~mL})$ and water $(10 \mathrm{~mL})$ were added and the mixture was stirred for several minutes. The organic phase was washed with water and dried $\left(\mathrm{Na}_{2} \mathrm{SO}_{4}\right)$. The crude product obtained after evaporating the solvent was purified by preparative TLC (silica gel, hexane-ethyl acetate, $10: 1$ as the eluant) to give pure adducts 24. Yield: $0.21 \mathrm{~g}(48 \%)$. m.p.: 146$148{ }^{\circ} \mathrm{C} .[\alpha]_{\mathrm{D}}{ }^{20}=-58.2$ (c. $\left.1.0, \mathrm{CH}_{2} \mathrm{Cl}_{2}\right), 72 \%$ ee for $(-)-(S)$ enantiomer. ${ }^{1} \mathrm{H}$ NMR $(500 \mathrm{MHz}$, $\left.\mathrm{CDCl}_{3}\right) \delta: 7.85(\mathrm{~d}, 2 \mathrm{H}, \mathrm{COPhH}-\mathrm{o}), 7.53$ (t, 1H, COPhH-p), 7.42 (t, 2H, COPhH-m), 7.18-7.32 (m, 5H, CHPhH), 4.15 (dd, $J=10.4,3.3 \mathrm{~Hz}, 1 \mathrm{H}, \mathrm{CH}), 3.67$ (dd, $J=17.2,10.4 \mathrm{~Hz}, 1 \mathrm{H}, \mathrm{CH}_{2}$ ), 3.27 (dd, $J=17.2,3.2 \mathrm{~Hz}, 1 \mathrm{H}, \mathrm{CH}_{2}$ ), 1.63 (s, $\left.3 \mathrm{H}, \mathrm{CH} 3\right), 1.54$ (s, $3 \mathrm{H}, \mathrm{CH}_{3}$ ) ppm. HRMS: $m / z$ $[\mathrm{M}]^{+}$calcd for $\mathrm{C}_{18} \mathrm{H}_{19} \mathrm{NO}_{3}: 297.1365$; found: 297.1367.

\section{General procedure for the epoxidation of chalcones ${ }^{7}$}

A mixture of $0.3 \mathrm{~g}$ chalcone $(1.44 \mathrm{mmol})$, the appropriate catalyst $(0.1 \mathrm{mmol})$ in $3 \mathrm{~mL}$ toluene and $1 \mathrm{~mL} 20 \% a q$. NaOH was treated with $0.5 \mathrm{~mL} 5.5 \mathrm{M}$ tert-butyl hydroperoxide in decane ( $2.88 \mathrm{mmol})$. The mixture was stirred at $4-5{ }^{\circ} \mathrm{C}$ for $4-10$ hours. New portion of toluene $(7 \mathrm{~mL})$ and water $(10 \mathrm{~mL})$ were added and the mixture was stirred for several times. The organic phase was washed with $10 \%$ aqueous hydrochloric acid $(2 \times 10 \mathrm{~mL})$ and then with water $(10 \mathrm{~mL})$. The 
organic phase was dried $\left(\mathrm{Na}_{2} \mathrm{CO}_{3}\right)$. The crude product obtained after evaporating the solvent was purified by preparative $T L C$ (silica gel, hexane-ethyl acetate, 10:1 as the eluant) to give $\mathbf{2 5}$ in a pure form. Yield: $0.16 \mathrm{~g}$ (38\%). m.p.: $64-66{ }^{\circ} \mathrm{C}$. $[\alpha]_{\mathrm{D}}{ }^{20}=-115.5$ (c. $1.0, \mathrm{CH}_{2} \mathrm{Cl}_{2}$ ), 54\% ee for $(2 R, 3 S)$ enantiomer; ${ }^{1} \mathrm{H}$ NMR $\left(300 \mathrm{MHz}, \mathrm{CDCl}_{3}\right) \delta: 8.02(\mathrm{~d}, 2 \mathrm{H}, \mathrm{COPhH}-o), 7.63(\mathrm{t}, 1 \mathrm{H}$, COPhH-p), 7.50 (t, 2H, COPhH-m), 7.38-7.44 (m, 5H, CHPhH), 4.30 (d, J=1.9 Hz, 1H, CH), 4.09 (d, $J=1.9 \mathrm{~Hz}, 1 \mathrm{H}, \mathrm{CH})$. HRMS: $m / z$ calcd for $\mathrm{C}_{15} \mathrm{H}_{12} \mathrm{O}_{2}[\mathrm{M}]^{+}:$224.0837; found: 224.0830.

\section{Acknowledgements}

Financial support by the Hungarian Scientific Research Found (OTKA No. K 75098) is gratefully acknowledged.

\section{References}

1. (a) Kyba, E. P.; Timko, J. M.; Kaplan, L. J.; de Jong, F.; Gokel, G. W.; Cram, D. J. J. Am. Chem. Soc., 1978, 100, 4555. (b) Cram, D. J.; Sogah, G. D. Y. J. Am. Chem. Soc. 1985, 107, 8301. (c) O' Donnell, M. I. In Catalytic Asymmetric Synthesis; Ojima, I., Ed.; Asymmetric Phase-Transfer Reactions; VCH: New York, 2000; pp 727-755. (d) Comprehensive Asymmetric Catalysis; Jacobsen, E. N.; Pfaltz, A.; Yamamoto, H., Eds.; Springer: New York, 1999; p 241.

2. Jarosz, S.; Listkowski, A. Current Org. Chem. 2006, 10, 643.

3. (a) Stoddart, J. F. Top. Stereochem. 1987, 17, 207. (b) Miethchen, R.; Fehring, V. Synthesis 1998, 94. (c) Faltin, F.; Fehring, V.; Miethchen, R. Synthesis 2002, 1851.

4. (a) Alonso-Lopez, M.; Jimenez-Barbero, J.; Martin-Lomas, M.; Pemades, S. Tetrahedron 1988, 44, 1535. (b) Van Maarschalkerwaart, D. A. H.; Willard, N. P.; Pandit, U. K. Tetrahedron 1992, 48, 8825. (c) Aoki, S.; Sasaki, S.; Koga, K. Heterocycles 1992, 33, 493. (d) Kanakamma, P. P.; Mani, N. S.; Maitra, U.; Nair, V. J. Chem. Soc., Perkin Trans. 1 1995, 2339. (e) Töke, L.; Bakó, P.; Keserü, Gy. M.; Albert, M.; Fenichel, L. Tetrahedron 1998, 54, 213 and references cited therein. (f) Itoh, T.; Shirakami S. Heterocycles, 2001, 55, 37.

5. Bakó, P.; Tőke, L. J. Incl. Phenom. 1995, 23, 195.

6. (a) Bakó, P.; Czinege, E.; Bakó, T.; Czugler, M.; Töke, L. Tetrahedron:Asymmetry 1999, 10, 4539. (b) Bakó, T.; Bakó, P.; Szöllősy, Á.; Czugler, M.; Keglevich, Gy.; Töke, L. Tetrahedron: Asymmetry 2002, 13, 203. (c) Bakó, T.; Bakó, P.; Keglevich, Gy.; Báthori, N.; Czugler, M.; Tatai, J.; Novák, T.; Parlagh, Gy.; Tőke, L. Tetrahedron:Asymmetry 2003, 14, 1917-1923.

7. (a) Bakó, T.; Bakó, P.; Keglevich, Gy.; Bombicz P.; Kubinyi, M.; Pál, K.; Bodor, S.; Makó, A.; Tőke, L. Tetrahedron: Asymmetry 2004, 15, 1589. (b) Bakó, P.; Makó, A.; Keglevich, 
Gy.; Kubinyi, M.; Pál, K. Tetrahedron: Asymmetry 2005, 16, 1861.

8. (a) Zhang, X.-X.; Bradshaw, J. S.; Izatt, R. M. Chem. Rev. 1997, 97, 3313. (b) Samu, E.; Huszthy, P.; Horváth, Gy.; Szöllősy Á.; Neszmélyi, A. Tetrahedron: Asymmetry 1999, 10, 3615. (c) Köntös, Z.; Huszthy, P.; Bradshaw, J. S.; Izatt, R. M. Enantiomer 2000, 5,561

9. (a) Bradshaw, J. S.; Huszthy, P.; Wang, T.-M.; Zhu, C.-Y.; Nazarenko, A. Z.; Izatt, R. M. Supramolecular Chem. 1993, 1, 267. (b) Horváth Gy.; Huszthy, P.; Szarvas, Sz.; Szokán, Gy.; Redd, J. T.; Bradshaw, J. S.; Izatt, R. M. Ind. Eng. Chem. Res. 2000, 39, 3576.

10. (a) Bradshaw, J. S.; Nakatsjui, Y.; Huszthy, P.; Wilson, B. E.; Dalley, N. K.; Izatt, R. M. J. Heterocycl. Chem. 1986, 23, 353.

11. Horváth, Gy.; Rusa, C.; Köntös, Z.; Gerencsér, J.; Huszthy, P. Synth. Commun. 1999, 29, 3719, and referenced herein.

12. Newcomb, M.; Timko, J. M.; Walba, D. M.; Cram, D. J. J. Am. Chem. Soc. 1977, 99, 6392.

13. Cabezon, B.; Cao, J.; Raymo, F. M.; Stoddart, J. F.; White, A. J. P.; Williams, D. J. Chem. Eur. J. 2000, 6, 2262.

14. Bell, T. W.; Cheng, P. G.; Newcomb, M.; Cram, D. J. J. Am. Chem. Soc. 1982, 104, 5185.

15. Marchand, A. P.; Chong, H.-S.; Takhi, M.; Power, T. D. Tetrahedron, 2000, 56, 3121.

16. Dale, J.; Laidler, A.; Stoddart J. F. Carbohydr. Res., 1977, 55, 1.

17. Pietraszkiewicz, M; Juczak, J. Tetrahedron, 1984, 40, 2967.

18. Kanth, J. V. B.; Periasamy, M. J. Org. Chem. 1991, 56, 5964.

19. Johnstone, R. A.; Lewis, I. A. S.; Rose, M. E. Tetrahedron, 1983, 39,1597.

20. Stibor, I.; Holy, P.; Závada, J.; Koudelka, J.; Novák, J.; Zajicek, J.; Belohradsky, M. J. Chem. Soc. Chem. Commun. 1990, 1581.

21. Tsukube, H.; Inoue, T.; Hori, K. J. Org. Chem. 1994, 59, 8047.

22. Bakó, P.; Fenichel, L.; Tőke, L.; Czugler, M. Liebigs Ann. Chem. 1981, 1163. 